STUDI

FRANCESI

\section{Studi Francesi}

Rivista quadrimestrale fondata da Franco Simone

180 (LX | III) | 2016

Varia

\title{
Français et langues de France dans le théâtre du XVII siècle, éd. B. Louvat-Molozay
}

\section{Laura Rescia}

\section{OpenEdition}

\section{Journals}

\section{Edizione digitale}

URL: http://journals.openedition.org/studifrancesi/5318

DOI: 10.4000/studifrancesi.5318

ISSN: 2427-5856

\section{Editore}

Rosenberg \& Sellier

\section{Edizione cartacea}

Data di pubblicazione: 1 dicembre 2016

Paginazione: 523

ISSN: 0039-2944

\section{Notizia bibliografica digitale}

Laura Rescia, "Français et langues de France dans le théâtre du xvı" siècle, éd. B. Louvat-Molozay », Studi Francesi [Online], 180 (LX | III) | 2016, online dal 01 janvier 2017, consultato il 18 septembre 2020.

URL : http://journals.openedition.org/studifrancesi/5318; DOI : https://doi.org/10.4000/studifrancesi. 5318

Questo documento è stato generato automaticamente il 18 settembre 2020.

\section{(c) (i) (9)}

Studi Francesi è distribuita con Licenza Creative Commons Attribuzione - Non commerciale - Non opere derivate 4.0 Internazionale. 


\title{
Français et langues de France dans le théâtre du XVII siècle, éd. B. Louvat- Molozay
}

\author{
Laura Rescia
}

\section{NOTIZIA}

Français et langues de France dans le théâtre du XVII siècle, sous la direction de B. LOUVATMOLOZAY, «Littératures classiques» 87/2015, 342 pp.

1 A partire dalla seconda metà del XVII secolo, nel teatro francese si assiste alla nascita di un gran novero di personaggi che si esprimono in parlers diversi - varietà regionali o extraterritoriali. Tale fenomeno era già stato studiato ma soltanto occasionalmente $\mathrm{e}$ soprattutto in relazione a Molière. Gli studi raccolti in questo numero della rivista «Littératures classiques» si propongono di riprendere e approfondire le indagini relative al plurilinguismo teatrale nel Grand Siècle, descrivendone l'emergenza anche al di fuori del corpus molieresco, per interrogarsi sugli usi, modelli, significati di un evento che potrebbe apparire contraddittorio in un momento notoriamente significativo per l'uniformizzazione e stabilizzazione della lingua nazionale. La prospettiva letteraria, che rimane centrale in molti articoli, viene arricchita da quella linguistica, socio-linguistica e storica: e se una sezione importante del volume è pur sempre dedicata a Molière, altre affrontano con taglio comparatistico (relativo a Italia, Inghilterra e Francia) la stessa problematica, e altre ancora sono dedicate al teatro di provincia (occitano e bretone in particolare) e agli sviluppi del fenomeno nel secolo successivo.

2 Come fa rilevare la curatrice del volume nella sua introduzione, da questi contributi emergono almeno due direzioni di ricerca innovative. In primo luogo, appare ora evidente che considerare il plurilinguismo teatrale unicamente in relazione alla produzione di effetti di comicità è assai restrittivo, mentre più produttivo sembrerebbe 
esaminarne la funzione di richiamo alla necessità del monolinguismo, alle ragioni politiche di tale direzione, che giustificano l'apparire di violente satire contro il Midi. Inoltre, si è sempre considerato che le "lingue di Francia" - o, se si vuole, i dialetti francesi-portate in scena non fossero che un riflesso fortemente deformato della realtà, quando non un'invenzione d'autore, piuttosto distante dall'uso documentato: diversi articoli qui raccolti sottolineano invece come l'osservazione linguistica degli autori di secondo Seicento fosse particolarmente acuta, e alla base della decisione di riprodurre con grande fedeltà e precisione fenomeni linguistici come il betacismo dell'occitano o la creolizzazione dei parlers suisses.

3 Segnaliamo in particolare per il suo carattere fortemente innovativo l'articolo di Claude BOURQUI, "Monsieur de Pourceaugnac" et les enjeux de la prononciation du français, che mette in relazione la controversia sulla riforma dell'ortografia, inaugurata dalla pubblicazione nello stesso anno delle Véritables Règles de l'ortografe francéze di Lesclache e della commedia di Molière. Coloro che reclamano una modifica dell'ortografia del francese, nella direzione della sua semplificazione e adattamento alla pronuncia, si scontrano con i difensori dell'ortografia etimologica, che argomentano la necessità di mantenere la complessità della resa grafica in lingua francese a fronte della pluralità di pronunce, dei provinciali come degli stranieri. Secondo Bourqui, la commedia di Molière rifletterebbe questo dibattito, pur se in chiave umoristica. 